\title{
PELUANG IMPLEMENTASI TEKNOLOGI BIG DATA DAN BLOCK CHAIN UNTUK PENINGKATAN KINERJA PERDAGANGAN PADA SEKTOR UMKM DI INDONESIA PADA ERA INDUSTRI 4.0
}

\section{A Big Data and Block Chain Implementation Opportunity to Increase Trading Performance for Indonesian SME Sector in Industry 4.0 Era}

\author{
M Zaky Hadi \\ Jalan Terusan Ryacudu, Lampung Selatan, \\ Institut Teknologi Sumatera
}

\begin{abstract}
Industry 4.0 is the main challenge in business environment resulted from disruption technology. It has been affected many sectors in development country including SME in Indonesia. This paper provides a literature review on big data and block chain implementation opportunity to increase trading performance for indonesian SME sector in industry 4.0 era. A systematic literature review (SLR) was implemented to review the literature analysis, provide gap and recommendation to future research and managerial implementation on Indonesian SME. We found a system development on Big Data and how Indonesian government implements the system is the main challenge in this research area.
\end{abstract}

Keywords: Big Data, Block Chain, SME, Trading Performance

\begin{abstract}
ABSTRAK: Industry 4.0 adalah tantangan utama pada lingkungan bisnis sebagai hasil dari gangguan perkembangan teknologi yang eksponensial. Tantangan ini mempengaruhi banyak sektor pada negara-negara berkembang termasuk usaha kecil menengah mikro di Indonesia. Paper ini membahas kajian literatur tentang peluang implementasi big data dan block chain untuk meningkatkan kinerja perdagangan pada pada sektor UMKM di Indonesia untuk menghadapi era revolusi industry 4.0. Suatu metode Systematic Literature Review (SLR) diimplementasikan untuk menganalisis literatur, kesenjangan (gap) dan rekomendasi untuk riset kedepan dan implementasi manajerial pada UMKM di Indonesia. Penelitian menemukan bahwa pengembangan sistem big data dan kebijakan serta peran pemerintah dalam mengimplementasikan teknologi ini untuk meningkatkan kinerja perdagangan UMKM menjadi tantangan utama kedepannya.
\end{abstract}

Kata kunci : Big Data, Block Chain, Kinerja Perdagangan, UMKM 


\section{PENDAHULUAN}

Usaha mikro kecil menengah (UMKM) merupakan sektor pelaku bisnis yang memiliki anggota dan besaran usaha (modal, ruang lingkup usaha, jenis produk, aset, omset dan variabel bisnis lainnya) yang relatif berukuran kecil dibandingkan perusahaan besar lainnya yang cenderung memiliki nilai bisnis triliyunan. Meskipun demikian, unit usaha UMKM memiliki jumlah yang sangat banyak dibandingkan dengan perusahaan besar dan cenderung tahan terhadap krisis ekonomi di Indonesia yang dibuktikan dengan tumbangnya banyak perusahaan besar pada krisi ekonomi pada tahun 1998, namun bisnis UMKM justru tak goyah dan malah menjadi tulang punggung perekonomian di kala itu (Magnusson and Berggren, 2018). Sehingga, jenis usaha ini memiliki peran yang besar bagi perekonomian di Indonesia dan sudah tentu mendapat perhatian lebih dari pemerintah untuk mendukung keberlangsungan dan kekuatan ekonomi Indonesia.

Modal yang relatif kecil dan cenderung tahan terhadap ketidakpastian lingkungan bisnis makro menjadikan UMKM sebagai kegiatan ekonomi rakyat yang tidak hanya memiliki peran vital bagi kegiatan bisnis dan ekonomi Indonesia, namun juga memiliki posisi yang sangat strategis untuk menyerap tenaga kerja lebih banyak dibandingkan usaha besar (Huda, 2012). Sebagai contoh, UMKM di Australia menguasai hampir $98 \%$ dari bisnis Australia, berkontribusi terhadap sepertiga devisa negara dan mampu menyerap tenaga kerja hingga 4.7 juta jiwa. Di Chili, pada tahun 2014, 98.5\% usaha yang ada pada negara itu diklasifikasikan sebagai UMKM. Di Tunisia, wirausaha berkontribusi sebesar $28 \%$ dari total usaha pekerja nonpertanian dan perusahaan besar dengan total serapan tenaga kerja sebesar $62 \%$. Umumnya pada negara berkembang UMKM memiliki share market yang lebih besar dibandingkan negara maju(Bouma et al., 2011). UMKM juga dikatakan mampu melakukan driving inovasi dan mampu berkontribusi pada persaingan pada banyak sektor ekonomi.

Khusus di Indonesia sebagai salah satu negara berkembang di Kawasan Asia Tenggara dan memiliki penduduk terbanyak keempat di dunia, serta memiliki luasan area terbesar di Kawasan Asia Tenggara dan memiliki lebih dari 13 juta pulau, UMKM berkontribusi hingga 95\% dari sektor bisnis dan wirausaha di Indonesia. Besarnya jumlah penduduk, luasnya wilayah dan kekayaan sumberdaya alam di Indonesia menjadi alasan utama UMKM berkembang cukup pesat di Indonesia.

Perkembangan teknologi yang sangat eksponensial pada era saat ini serta disruption technology menjadikan tantangan industri 4.0 menjadi suatu tantangan sekaligus peluang yang harus dihadapi UMKM di Indonesia untuk menjamin kemampuan kompetitif UMKM dalam bersaing pada pasar yang lebih luas, pengaruh teknologi yang luas dan signifikan serta ketidakpastian lingkungan bisnis (Pääkkönen and Pakkala, 2015a). Sehingga penting untuk mengkaji peluang pengembangan model transfer teknologi, inovasi dan pengetahuan baik itu dari pemerintah maupun pihak akademisi akan mendorong tumbuh dan kekarnya UMKM di Indonesia terhadap perubahan zaman dan ekonomi yang sangat tidak pasti saat ini

Berdasarkan Rakernas Ristekdikti yang dilaksanakan di Universitas Sumatera Utara pada tahun 2018, fokus pengembangan ilmu pengetahuan dan teknologi (IPTEK) serta industri untuk menghadapi era disrupsi teknologi menuju revolusi industri 4.0 ada Sembilan bidang yaitu Internet of Things, Big Data, Cloud Computing, Artificial Intelligence, Robotics, Additive Manufacturing 3D, New Material, Augmented Reality, Nano Technology and Biotechnology serta block chain yang sangat popular pada perdagangan bit coin dan memperkuat daya saing rantai pasok pertanian dan UMKM .

Namun yang menjadi masalah pengembangan dan edukasi teknologi big data dan block chain di Indonesia adalah masih rendahnya pengetahuan pelaku 
UMKM akan pentingnya aspek keberlanjutan untuk kesuksesan usaha mereka di masa depan. Umumnya UMKM di Indonesia masih memikirkan satu aspek keberlanjutan saja yaitu aspek ekonomi. Jika dilakukan transfer teknologi dengan baik dalam bentuk implementasi teknologi praktis yang dapat meningkatkan omset UMKM maka peluang implementasi menjadi sangat terbuka luas. Sehingga strategi transfer pengetahuan, teknologi, inovasi baik secara top-down (dari pemerintah ke UMKM) maupun bottom-up (dari masyarakat ke UMKM) serta secara horizontal melalui interaksi dengan akademisi menjadi penting untuk dilakukan. Namun pengembangan model dan implementasi strategi keberlanjutan masih menjadi tantangan yang harus diselesaikan pihak akademisi dan pemerintah melalui sistem inovasi nasional dan riset-riset bidang pengambangan dan implementasi teknologi pada UMKM di Indonesia.

Artikel ini membahas peluang implementasi Big Data dan Block Chain untuk memperkuat daya saing UMKM di Indonesia, tantangan dan peluang pengembangan kedepannya. Masih rendahnya literasi, transfer teknologi, difusi dan transfer pengetahun menjadikan tantangan yang harus dihadapi untuk pengembangan UMKM berbasis teknologi di Indonesia. Namun hal ini bukan tanpa peluang mengingat "anak millennial" dewasa ini sangat menyukai model bisnis start-up berbasis teknologi. Sehingga peluang transfer teknologi menjadi terbuka lebar. Berdasarkan alasan tersebut kajian dan pengembangan teknologi Big Data dan Block Chain untuk memperkuat sektor perdagangan UMKM menjadi penting

Artikel ini mencoba memberikan gambaran mengenai pentingnya pengambangan teknologi big data dan block chain serta aspek-aspeknya pada peningkatan kompetitif UMKM Indonesia. Tulisan disusun dengan memberikan gambaran singkat mengenai usaha mikro kecil mengenah di Indoneisa, konsep keerlanjutan pada suatu bisnis, kondisi saat ini keberlanjutan UMKM, konsep transfer pengetahuan dan konsep pembelajaran menuju UMKM berkelanjutan, tantangan pengembangan Big data dan block chain serta implementasinya pada UMKM, dan peluang pengembangan kedepan untuk menghadapi era industri 4.0. Artikel disusun dengan pendekatan kajian beberapa literatur dan riset-riset internasional mulai dari tahun 2015 hingga saat ini terkait UMKM dan mencoba menghubungkannya dengan kondisi dan implementasi di Indonesia serta memberikan gambaran umum mengenai peluang riset pada bidang keberlanjutan UMKM di Indonesia baik kepada akademisi maupun unsur pemerintahan di Indonesia.

\section{METODOLOGI}

SLR adalah metodologi yang paing banyak digunakan untuk secara sistematis mengumpulkan, meringkas, menganalisis dan mensintesis rujukan suatu kajian atau studi literatur, yang terdiri dari beberapa tahapan yang telah disepakati serta dapat dengan mudah diverifikasi dan diulangi oleh peneliti lainnya. Sehingga, SLR memiliki kunggulan pada transparansi, struktur umum metode yang dapat diterima oleh banyak peneliti, dan dapat mudah diulangi dibandingkan dengan kajian literatur sederhana.

Tahapan SLR terdiri dari 3 bagian utama yaitu tahapan persiapan (preparatory step), pencarian literatur (literature search) dan Analisis Sintesis (analysis and synthesis) (Barbara Kitchenham, 2007). Tahapan persiapan terdiri dari 3 yaitu pengembangan protokol kjian literatur, pengembangan dan evaluasi pertanyaan riset, menetapkan kriteria inklusi. Tahapan pencarian literatur terdiri dari pemilihan basisdata (selecting database), melakukan pencarian rujukan yang akan dikaji (conducting the study search), mengevaluasi kualitas dan komprehensifitas pencarian (Evaluating the Quality and Comprehensiveness of the Search), menyaring literatur (filtering studies)(Ahmed et al., 2018). Tahapan analisis dan sintesis terdiri dari ekstraksi data (data extracting), 
melakukan evaluasi biasa pada literatur yang dikaji (assessing for bias in included studies), analisis data (analyzing data), sintesis dan interpretasi hasil (synthesizing and interpreting results)

\section{A. Tahapan persiapan (preparatory step)}

Tahapan persiapan terdiri dari pendefinisian pertanyaan yang akan digunakan untuk mencari literatur pada tahapan sebelumnya. Pertanyaan yang disusun pada tahapan persiapan ini adalah : Bagaimana kondisi dan kesiapan UMKM di Indonesia?, Bagaimana peluang implementasi Big Data di Indonesia?, Apa tantangan dan rekomendasi kedepan?. Selanjutnya dilakukan pendefinisian kriteria inklusi berupa ketersediaan literatur dalam bentuk full text, rentang periode publikasi pada tahun 2010-2016, serta keterkaitan kajian pada implementasi big data dan block chain

\section{B. Tahapan pencarian literatur (literature search)}

Tahapan ini terdiri dari pencarian literatur basisdata yang akan digunakan untuk mencari paper dan kajian terkait meliputi ABI Inform Global, Science Direct, Emerald Insight, and Scopus, IEEE, Springer, Cambridge, Oxford. Lalu melakukan kajian terkait kata kunci UMKM (Small Medium Enterprises), Big Data dan Block Chain untuk membatasi ruang lingkup kajian. Setelah itu melakukan filtering pada paper terpilih berdasarkan kualitas dan komprehensifitas kajian.

\section{Analisis dan Sintesis}

Analisis dan sitensis dilakukan untuk melakukan ekstraksi data pada paper berupa tujuan, metode, hasil, implikasi manajerial serta peluang implementasi riset kedepannya. Setelah itu dilakukan sintesis dan interpretasi hasil.

\section{HASIL DAN PEMBAHASAN}

\section{A. UMKM Indonesia pada Era Industri 4.0}

UMKM memainkan peranan penting pada pertumbuhan ekonomi di Indonesia dan terbukti mampu bertahan pada krisis ekonomi pada tahun 1998 yang dibuktikan dari data statistic pasca krisis ekonomi tahun 1997-1998 jumlah UMKM tidak berkurang, justru meningkat terus, bahkan mampu menyerap 85 juta hingga 107 juta tenaga kerja sampai tahun 2012 (BI 2015) dengan jumlah pengusaha di Indonesia sebanyak 56.539 .560 unit dengan jumlah Usaha Mikro Kecil dan Menengah (UMKM) sebanyak 56.534.592 unit atau 99.99\%. Sisanya, sekitar $0,01 \%$ atau 4.968 unit adalah usaha besar.

Hingga Desember 2012 Indonesia memiliki 69,249 yang sangat berpotensi untuk pengembangan usaha kecil menengah yang cenderung menjual produkproduk khas suatu daerah dan tradisional dengan modal yang kecil (Irjayanti and Mulyono, 2012). Secara umum tantangan yang harus dihadapi era technological disruption ini adalah melakukan manajemen finansial perdagangan, manajemen organisasi UMKM dan inovasi menuju industri 4.0. Pemerintah dan organisasi telah banyak melakukan pelatihan manajemen organisasi dan finansial kepada UMKM untuk memperbaiki kinerja bisnis mereka. Tantangan yang masih dihadapi pemerintah dewasa ini adalah pengembangan model UMKM menuju revolusi Industri 4.0 melalui penguatan literasi dan penggunaan teknologi kepada UMKM untuk meningkatkan kinerja kompetitif mereka pada pasar global. Salah satunya adalah inovasi pada pengembangan big data dan block chain untuk UMKM. Tentunya desain sistem ini tidak realistis jika diminta UMKM untuk mengembangkan secara mandiri karena faktor literasi teknologi dan biaya pengembangan.

Kolaborasi antara pemerintah dan akademisi menjadi penting untuk pengembangan suatu sistem berbasis big 
data dan block chain untuk memperkuat persaingan kompetitif UMKM Indonesia pada era industri 4.0 dan globalisasi. Transfer teknologi dan difusi pengetahuan menjadi penting pada pelaku UMKM dalam memperkuat penggunaan sistem berbasis big data dan block chain dan literasi teknologi yang harus dilakukan pemerintah dan akademisi.

Tahap selanjutnya paper ini akan menjelaskan penjelasan umum tentang teknologi big data dan manfaatnya pada peningkatan keunggulan kompetitif UMKM Indonesia pada pedagangan global

\section{B. Teknologi Big Data}

Menurut (Brynjolfsson, 2012) pada era teknologi yang tumbuh eksponensial dewasa ini ledakan data besar terjadi tanpa disadari dan memungkinkan untuk pengembangan sistem pengambilan keputusan secara real time. Data tersebar dan tersedia dalam jumlah besar yang menuntut tantangan pada bidang keilmuan apapun untuk dapat mengumpulkan dan menginterpretasikan informasi, keputusan dan pengetahuan dari jumlah data yang sangat besar tersebut. Data yang tersedia cukup besar ini dapat digunakan oleh pengambil keputusan untuk mengukur, serta mengetahui secara komprehensif dan cepat apa saja yang terjadi pada bisnis mereka secara real time.

Dengan adanya data yang voluminous ini, UMKM-UMKM yang ada pada saat ini seharusnya dapat memanfaatkannya untuk pengembangan keunggulan kompetitif mereka secara cepat yang tidak dapat dilakukan oleh perusahaan-perusahaan beberapa puluh tahun yang lalu. Namun, penggunaan big data pada UMKM memiliki peluang untuk mentransformasi UMKM tradisional menjadi UMKM berbasis teknologi informasi. Faktanya Big Data analitik sangat powerfull untuk meningkatkan keunggulan bisnis suatu organisasi atau perusahaan dibandingkan perangkat analisis kondisi perusahaan yang dilakukan pada masa lalu. UMKM dapat mengelola dan melakukan pengukuran berbagai lini bisnis mereka secara lebih presisi. Sehingga dapat melakukan pengambilan keputusan yang lebih cerdas dan prediksi yang lebih baik. UMKM dapat mentarget suatu tujuan dari bisnis mereka menjadi lebih efektif dan terukur berdasarkan data dan ketelitian dibandingkan yang selama ini dilakukan secara intuisi(Tao et al., 2017).

Secara umum big data didefinisikan sebagai suatu bidang yang berusaha menganalisis dan mengekstrak informasi secara sistematis, serta menangani sekumpulan data yang terlalu besar dan kompleks untuk ditangani oleh perangkat lunak dan metode-metode tradisional. Data dengan ukuran kasus (baris) yang besar membutuhkan kekuatan statistik yang lebih besar juga untuk mengolahnya menjadi informasi. Sementara data dengan atribut yang banyak dan kompleksitas yang besar dapat menyebabkan kesalahan interpretasi data pada proses pencarian informasi dan pengetahuan yang terkandung pada suatu big data. Tantangan-tantangan yang harus dihadapi dalam mengolah big data adalah melakukan capturing data, penyimpanan, analisis, searching and sharing, transfer, visualisasi, querying, pembaharuan, privasi informasi, dan sumber data. Big data pada awalnya diasosiasikan dengan tiga konsep kunci yaitu volume, variasi dan kecepatan. Konsep selanjutnya menambahkan kebenaran data, dan nilai.

Pengembangan teknologi big data untuk meningkatkan keunggulan kompetitif UMKM oleh pemerintah dan akademisi perlu dilakukan untuk melakukan analisis prediktif, perilaku, meupun metode-metode analisis data lainnya yang melakukan ekstraksi suatu nilai dari data atau analisis lainnya yang jarang dilakukan pada data ukuran kecil. Penggunaan big data analytics dapat menghasilkan suatu dashboard pada desain sistem business intelligence sehingga bermanfaat terhadap perkembangan bisnis dan perdagangan sektor UMKM, mengetahui spot suatu bisnis, menghentikan penyebaran suatu penyakit yang ditimbulkan dari pedagang kaki lima yang tidak hygiene, perbuatan 
kriminal pada bisnis dan perdagangan dan lain sebagainya.

Pengembangan ini haruslah melalui kerjasama antara peneliti, pelaku bisnis, medis dan obat-obatan, media dan pemerintah dalam mengembangkan suatu sistem big data analytics. Output dari kerjasama ini adalah suatu sistem pengolahan big data terintegrasi pada berbagai bidang seperti sistem pencarian di internet, finansial teknologi, urban informatics, dan business informatics untuk perkembangan UMKM (Pääkkönen and Pakkala, 2015b).

Dengan adanya big data analytics, pemerintah dapat melakukan perbaikan dan pelatihan penggunaan perangkat lunak pengolah big data pada UMKM untuk perencanaan suplai dan kualitas bahan baku. Big data dapat mendukung pemerintah dalam menyediakan infrastruktur dan transparansi bagi keberlanjutan sektor UMKM di Indonesia. Selain itu juga membantu UMKM dalam menghadapi ketidakpastian bisnis seperti ketidakkonsistenan salah satu tolak ukur kinerja bisnis dan ketersediaan produk dan bahan baku. Selain itu membentuk UMKM dalam mengefisiensikan biaya produksi, meningkatkan produktivitas dan membantu mempermudah difusi inovasi dari pemerintah dan perguruan tinggi kepada UMKM melalui proses pembelajaran online.

Berdasarkan keunggulan-keunggulan big data tersebut penting bagi pemerintah untuk melakukan tahapan awal penelitianpenelitian bidang big data mengingat bidang ini adalah salah satu tantangan menuju revolusi industri 4.0. Tahap selanjutnya setelah mengembangkan sistem big data analytics adalah melakukan difusi teknologi tersebut kepada UMKM sehingga mereka mendapatkan literasi teknologi yang cukup untuk mengoperasikan perangkat lunak pembantu pengambil keputusan dan membantu dalam meningkatkan level kompetitif bisnis dan perdagangan UMKM (Sarosa, 2012). Indonesia saat ini perlu membuat prototipe level pilot plant untuk selanjutnya diujicobakan secara komersial dan melakukan pelatihan kepada UMKM.

Setelah pengembangan big data salah satu tantangan pada bidang ini adalah ketertelusuran dan keamanan data yang sangat baik diintegrasikan dengan block chain untuk menghasilkan suatu sistem big data analytics yang powerfull. Selanjutnya paper ini mencoba membahas pentingnya teknologi block chain untuk peningkatan strategi kompetitif UMKM di Indonesia pada era globalisasi dan disruption technologies.

\section{Teknologi Block Chain}

Block chain secara umum didefinisikan sebagai suatu blok penyimpanan data yang terus tumbuh seiring dengan semakin banyaknya transaksi dan dikunci dengan kunci pengaman digital menggunakan kriptografi. Setiap blok mengandung cryptographic hash dari blok yang terhubung sebelumnya, waktu transaksi dan data isi transaksi. Secara desain suati block chain sangat kekar terhadap modifikasi data, berbentuk susunan blok data terbuka dan terdistribusi yang mampu mencata transaksi antara dua pihak yang berbsinis secara efisien dengan cara yang dapat diverifikasi dan permanen. Jaringan blok data ini dikelola secara peer-to-peer secara kolektif mengikuti protocol komunikatif antar node dan melakukan validasi terhadap blok baru yang terbentuk. Setelah data transaksi direkam, data suatu blok tertentu tidak dapat diubah secara terpisah (retroaktif) tanpa melakukan perubahan terhadap blok berikutnya yang membutuhkan consensus jaringan pengelola block chain. Konsep jaringan blok data yang terdesentralisasi ini membuat teknologi block chain sangat baik digunakan pada proses traceability.

Secara umum teknologi block chain banyak digunakan pada transaksi uang digital seperti bit coin. Namun semakin berkembangnya model block chain dan teknologi informasi menjadikan aplikasi teknologi ini meluas. Seperti pada smart contracts, layanan finansial, video game dan rantai pasok serta pada proses bisnis lainnya. Aplikasi yang beragam pada proses bisnis ini memberi peluang peningkatan 
keuntungan kompetitif UMKM dalam menangani persaingan global.

Kontrak adalah salah satu instrument penting pada bisnis beberapa UMKM. Pengembangan smart contract berbasis block chain adalah kontrak yang dikembangkan untuk dapat dilaksanakan sebagian atau sepenuhnya tanpa campur tangan manusia. Tujuan utama dari smart contract ini adalah melakukan generate dokumen perjanjian secara otomatis. Smart contract berbasis teknologi block chain dapat mengurangi bahaya moral dan mengoptimalkan penggunaan kontrak secara umum. Namun perlu kajian terhadap status hukum sehingga dapat diterapkan secara otomatis pada sistem kontrak UMKM untuk mempercepat proses jual beli dan transaksi.

Implementasi pada layanan finansial adalah menjamin record data yang aman antara transaksi dua pelaku bisnis. Track record yang dapat dilacak dengan data yang lebih valid karena perlu konsorsium untuk mengubah data suatu block chain. Sehingga dapat membangun kepercayaan antara dua pelaku yang menjalankan kegiatan bisnis.

Aplikasi sangat luas juga dapat dilakukan pada logistik dan rantai pasok utamanya pertanian yang menjadi sektor produk olahan yang paling umum bagi model bisnis UMKM di Indonesia(Saridakis et al., 2019). Block chain menyediakan jaringan data yang memungkinkan suatu produk dapat ditelusuri hingga kebagian upstream sehingga dapat dilakukan tracking dan pemetaan UMKM mana saja yang kurang baik struktur rantai pasok dan kualitas produknya untuk dapat melakukan pelatihan jika ditemukan suatu masalah pada konsumen UMKM.

Pada aplikasinya, konsep desentralisasi block chain, dimana data disimpan pada user dan pelaku konsorsium tidak akan mampu menanggulangi handling data saat jumlah data transaksi yang semakin besar dan jaringan block chain yang semakin rumit, sehingga diperlukan integrasi dengan teknologi big data analytics. Penyediaan infrastruktur dan digitalisasi UMKM dengan record data pada infrastruktur big data Indonesia yang dibangun melalui suatu kerja sama antara akademisi dan pemerintah dapat membantu pemantauan kondisi UMKM saat ini via dashboard business intelligence dan membantu UMKM dalam memanejemen bisnis mereka secara real time. Tantangan pengembangan, implementasi dan deployment perlu dikaji secara lebih seksama.

Bagian selanjutnya akan dijelaskan peluang penerapan big data dan block chain untuk peningkatan kinerja perdagangan sektor UMKM.

\section{Penerapan Big Data dan Block Chain untuk Peningkatan Kinerja \\ Perdagangan Sektor UMKM}

Integrasi antara big data dan block chain akan menghasilkan infrastruktur pengolahan business analytics dan smart cities technology untuk membantu pemerintah dalam mengembangan UMKM di Indonesia sekaligus sebagai sarana mudah dan real time dalam mengembangkan sektor perdagangan UMKM melalui peningkatan produktivitas, kualitas, kemampuan ekspor, kemudahan birokrasi serta peningkatan daya saing pada pasar global.

Contoh kongkrit adalah peta sebaran UMKM di Indonesia berikut jenis produkproduk yang diperdagangkan. Sebaran UMKM yang dapat dilihat melalui peta secara real time pada teknologi business intelligence yang terintegrasi dengan block chain dan big data akan mempermudah pemantauan kondisi UMKM meliputi produk dengan jumlah arus perdagangan paling tinggi dan paling rendah secara real time, pertumbuhan UMKM, sebaran pendapatan, konsentrasi perdagangan, inflasi produkproduk tertentu sehingga lebih mudah untuk dilakukan penanggulangan secara top-down oleh pemerintah serta dasar pembuatan kebijakan yang lebih akurat.

Selain itu tersedianya pasar-pasar online dan sosial media seperti instagram yang sangat efektif dalam melakukan promosi produk juga dapat dianalisis dan didesain 
suatu sistem agar UMKM lebih mudah dalam mengaplikasikan dan menerapkannya dalam model bisnis mereka. Oleh karena itu pada implementasi penggunaan perangkat lunak yang telah didesain oleh pemerintah memerlukan pelatihan khusus dan kemudahan dalam menerapkan maupun melakukan transfer technology dari pengembangan (pemerintah dan universitas) kepada UMKM. Harapannya dengan adanya suatu sistem UMKM tersebut dapat mempermudah UMKM dalam menentukan model bisnis, arah bisnis, dan jenis produk yang akan diperdagangkan. Desain dan pengembangan suatu business intelligence untuk UMKM yang dikembangkan secara praktis berbasis big data dan block chain akan mempermudah UMKM untuk melakukan pengambilan keputusan bisnis dan perdagangan sehingga meingkatkan nilai kompetitif perdangangan UMKM di Indonesia pada pasar global. Contoh konkrit adalah UMKM dapat mengetahui jenis produk apa yang disukai konsumen saat ini, berapa jumlah investasi, produk apa yang paling menguntungkan untuk diperdagangkan, kemana saja harus diekspor dan birokrasi yang herus dipersiapkan dengan mudah. Dashboard pada business intelligence berbasis block chain dan big data juga dapat membantu UMKM dalam melihat pertumbuhan bisnis dan informasi-informasi pelatihan dari pemerintah. Kemudahan ktertelusuran pada rantai pasok bisnis juga membantu UMKM dalam menentukan mitra B2B yang memiliki performa bagus dalam memberikan jasa layanan bisnis seperti logistik maupun suplai bahan baku (Liu, 2014).

Meskipun demikian tentunya masih terdapat tantangan-tantangan yang harus dihadapi setiap aktor seperti pemerintah sebagai pembuat regulasi dan akademisi dalam emmpersiapkan penelitian dan pengembangan sistem. Bahasan selanjutnya akan memaparkan tantangantantangan dan hambatan dalam pengembangan sistem business intelligence UMKM berbasis big data dan block chain untuk menghadapi revolusi industri 4.0

\section{E. Tantangan dan Hambatan}

Peluang pengembangan sektor bisnis dan perdagangan yang bisa sangat cepat pada era ketersediaan data yang massif pada zaman technology disruption seperti saat ini. Adanya teknologi block chain yang mempermudah validasi dan keamanan data dapat menjawab tantangan big data yang membutuhkan validasi untuk mencegah noisy data dan tantangan privasi dan keamanan maupun ketertelusuran data. Namun dalam pengembangan dan implementasinya masih memiliki tantangan dan hambatan sebagai berikut

Big Data dan block chain adalah teknologi besar yang membutuhkan infrastruktur dan kesiapan sistem yang baik sehingga perlu kajian kesiapan teknologi pada sistem business intelligence untuk peningkatan performa perdagangan, produktivitas, kontrol dan penyuluhan UMKM yang baik hingga level 9 dalam skala technology readiness level. Kompleksitas sistem yang tinggi perlu untuk didesain dengan komrehensifitas, kemudahan pakai dan luaran yang benarbenar dibutuhkan oleh pemerintah dalam menentukan keputusan dan regulasi maupun UMKM sebagai pengguna. Setelah sistem dengan infrastruktur besar ini didesain tahap selanjutnya adalah tantangan melakukan transfer dan difusi teknologi pada UMKM melalui pelatihanpelatihan yang berorientasi pada keberlanjutan bisnis dan penjelasan manfaat dan kemudahan pakai pada UMKM sehingga pelaku bisnis UMKM tertarik menggunakannya dan mau melakukan literasi teknologi lebih dalam lagi. Implementasi dan pengembangan sistem ini tentunya memiliki tantangan teknis lain yang tidak dapat dijawab dalam waktu singkat namun penting dikembangkan sesegera mungkin mengingat teknologi berbasis business intelligence dan big data adalah salah satu bagian dari penguatan strategi kompetitif UMKM dalam menghadapi revolusi industri 4.0 
Teknologi yang relatif baru dan asing pada masyarakat Indonesia tentunya akan mendapat penolakan-penolakan pada beberapa daerah dan beberapa sektor UMKM yang cenderung hanya memperhatikan aspek keberlanjutan bisnis secara ekonomi saja tanpa memperhatikan peluang keberlanjutan kedepan baik itu untuk memperluas bisnis maupun menghadapi tantangan global melalui penguatan daya saing dan kemampuan kompetitif UMKM (Pacheco et al., 2018). Selain itu biaya pengembangan yang tinggi, kerumitan beberapa sektor rantai pasok UMKM, keunikan beberapa sektor perdagangan dan logistik produk UMKM serta masih belum meratanya infrastruktur listrik dan internet dalam menjangkau desadesa yang jauh dari pusat perkotaan yang umumnya bisnis didominasi oleh UMKM

\section{F. Saran-Saran Strategis Perdagangan}

Berdasarkan tantangan dan hambatan tersebut tulisan ini memberikan saran-saran pada berbagai sektor quadraple helix persiapan inovasi pengembangan big data dan block chain untuk membangun suatu sistem pusat pemantauan UMKM berbasis business intelligence baik itu pada aktor akademsi, pemerintah (top-down), UMKM dan industri maupun masyarakat yang umum menjadi konsumen dari produkproduk UMKM (Reardon et al., 2018). Perlu ada kesiapan suatu sistem dan infrastrukturnya, regulasi yang jelas pada berbagai lini bisnis yang didigitalisasi (termasuk penggunaan big data), kemudahan regulasi hingga pelatihanpelatihan untuk transfer teknologi. Pemerintah tentunya akan mendapat keuntungan berupa data yang valid dan besar secara real time sehingga pengambilan keputusan bisa lebih tepat. Ketersediaan data besar akan menjadi manfaat tersendiri dalam menigkatkan perdagangan dan industri pada sektor UMKM. Kerjasama antara pemerintah dan akademisi perlu ditingkatkan dan pelatihan dan uji coba perlu dilakukan sehingga dimasa depan UMKM Indonesia akan mendominasi pasar dalam negeri dan global yang secara langsung berdampak signifikan terhadap pertumbuhan ekonomi Indonesia khususnya di Kawasan Asia Tenggara.

\section{KESIMPULAN DAN PELUANG PENGEMBANGAN BIG DATA DAN BLOCK CHAIN PADA UMKM}

Pengembangan sistem business intelligence berbasis UMKM sangat penting pada era revolusi industri 4.0 untuk meningkatkan produktivitas dan daya saing global pada sektor UMKM yang secara langsung berkontribusi pada perngembangan ekonomi di Indonesia. Pengembangan business intelligence berbasis big data dan block chain akan mempercepat arus rantai pasok dan perdagangan dan mempermudah pemerintah dalam menentukan regulasi dan melakukan pengambilan keputusan maupun pelatihan-pelatihan yang perlu dilakukan kepada spesifik kepada UMKM tertentu. UMKM dapat memanajemen bisnis secara lebih tepat dengan adanya data yang lebih valid dan real time sehingga meningkatkan keunggulan kompetitif mereka. Meskipun demikina tantangan pengembangan infrastruktur dan difusi teknologi dalam bentuk pelatihan-pelatihan awal perlu dilakukan untuk memperkuat pondasi pengetahuan awal bagi pengembangan UMKM berbasis business intelligence yang terintegrasi dengan big data dan block chain. Adanya sistem ini akan mempercepat pertumbuhan sektor UMKM di Indonesia.

\section{DAFTAR PUSTAKA}

Ahmed, Y. A. et al. (2018) 'Social media for knowledge-sharing: A systematic literature review', Telematics and Informatics. Elsevier Ltd. doi: 10.1016/j.tele.2018.01.015.

Barbara Kitchenham, S. C. (2007) Guidelines for performing systematic literature reviews in software engineering version 2.3. Engineering, 
45(4ve).

Bouma, J. et al. (2011) The Role of Knowledge When Studying Innovation and the Associated Wicked Sustainability Problems in Agriculture. 1st edn, Advances in Agronomy. 1st edn. Elsevier Inc. doi: 10.1016/B978-012-386473-4.00011-7.

Huda, A. N. (2012) 'The Development of Islamic Financing Scheme for SMEs in a Developing Country: The Indonesian Case'. Aulia Nurul Huda, 52, pp. 179186.

doi: 10.1016/j.sbspro.2012.09.454.

Irjayanti, M. and Mulyono, A. (2012) 'Barrier Factors and Potential Solutions for Indonesian SMEs'. The Authors, 4(Icsmed), pp. 3-12. doi: 10.1016/S2212-5671(12)00315-2.

Liu, Z. (2014) 'Research on cultivating employment competence of students in applied engineering universities', World Transactions on Engineering and Technology Education, 12(2), pp. 196202. doi: $10.1108 / 13598540610682381$.

Magnusson, T. and Berggren, C. (2018) 'Competing innovation systems and the need for redeployment in sustainability transitions', Technological Forecasting and Social Change. Elsevier, 126(July 2016), pp. 217-230. doi: 10.1016/j.techfore.2017.08.014.

Pääkkönen, P. and Pakkala, D. (2015a) 'Big Data Research Reference Architecture and Classification of Technologies, Products and Services for Big Data Systems', Big Data Research. Elsevier Inc., 1, pp. 1-21. doi: 10.1016/j.bdr.2015.01.001.

Pääkkönen, P. and Pakkala, D. (2015b) 'Reference Architecture and Classification of Technologies, Products and Services for Big Data Systems', Big Data Research. Elsevier
Inc., 2(4), pp. 166-186. doi: 10.1016/j.bdr.2015.01.001.

Pacheco, D. A. de J. et al. (2018) 'Ecoinnovation determinants in manufacturing SMEs from emerging markets: Systematic literature review and challenges', Journal of Engineering and Technology Management - JET-M. Elsevier, 48(April), pp. 44-63. doi: 10.1016/j.jengtecman.2018.04.002.

Reardon, T. et al. (2018) 'Rapid transformation of food systems in developing regions: Highlighting the role of agricultural research \& innovations', Agricultural Systems. Elsevier, (September 2017), pp. 0-1. doi: 10.1016/j.agsy.2018.01.022.

Saridakis, G. et al. (2019) 'SMEs' internationalisation: When does innovation matter?', Journal of Business Research. Elsevier, 96(September 2017), pp. 250-263. doi: 10.1016/j.jbusres.2018.11.001.

Sarosa, S. (2012) 'Adoption of social media networks by Indonesian SME : A case study'. The Authors, 4(lcsmed), pp. 244-254. doi: 10.1016/S22125671(12)00339-5.

Tao, F. et al. (2017) 'Digital twin-driven product design, manufacturing and service with big data'. The International Journal of Advanced Manufacturing Technology. doi: 10.1007/s00170-0170233-1. 